\title{
Rodzicielstwo zastępcze w świetle zasady subsydiarności
}

Dziecko ma prawo do wychowania się w rodzinie. W sytuacji gdy rodzice nie są w stanie sprawować właściwej opieki nad swoim potomstwem, wówczas na podstawie orzeczenia sądu zostaje ono umieszczone w rodzinie zastępczej. Realizacja pomocy rodzinie i dziecku powinna się odbywać zgodnie z zasadą subsydiarności, według której umożliwia się jednostkom przezwyciężanie trudności życiowych, których nie są w stanie pokonać w własnym zakresie. Zasada pomocniczości pozwala na wyróżnienie zbioru dyrektyw, zasad, którymi powinien zajmować się zespół interdyscyplinarny zaangażowany w pomoc dziecku i rodzinie. Praca na rzecz dziecka i rodziny jest zadaniem niezwykle ważnym, gdyż ma na celu reintegrację rodziny, a przede wszystkim zapewnienie wychowankowi stabilnego i bezpiecznego środowiska wychowawczego. W niniejszym artykule zostały zaprezentowane kwestie związane z ideą rodzicielstwa zastępczego. Celem głównym opracowania jest zarysowanie problematyki rodzin zastępczych w świetle zasady pomocniczości. Idea rodzicielstwa zastępczego opiera się na niesieniu pomocy młodym wychowankom w kształtowaniu właściwych postaw, dążących do samodzielności dziecka i pełnienia ról społecznych. Artykuł 
jest także prezentacją fragmentu prowadzonych obecnie badań nad skutecznością procesu usamodzielniania się wychowanków z rodzin zastępczych.

\section{Rodzinna piecza zastępcza w ujęciu merytoryczno-prawnym}

W dyskursie społecznym często pojawiają się sformułowania dotyczące dziecka, jego praw czy też wsparcia rodziny. To właśnie rodzina jest podstawową instytucją w społeczeństwie, która ma wypełnić powierzone im funkcje. W sytuacji gdy rodzice nie są w stanie prawidłowo spełniać roli opiekuńczo-wychowawczej, wówczas państwo za pomocą różnych instytucji zapewnia dziecku bezpieczeństwo i warunki do stabilnego oraz prawidłowego rozwoju1. Termin „piecza” może być definiowany jako dbałość, opieka. Określenie to odnosi się do ciągłego i bezinteresownego zaspokajania przez opiekuna potrzeb dziecka (których ono samo nie jest zdolne zaspokoić) $)^{2}$. Z kolei termin „zastępcza” wymaga dookreślenia, czy głównym zadaniem jest wyręczenie rodziców biologicznych, czy raczej udzielenie im pomocy w wypełnianiu zadań wobec dzieci. Może być również rozumiany jako próba wypełnienia braków w opiece naturalnej, rodzicielskiej rodziny biologicznej dziecka, w celu zapewnienia prawidłowo funkcjonującej rodziny oraz przekazania właściwych norm społecznych. Termin „zastępcza" może także wskazywać na tymczasowy charakter pieczy nad dzieckiem $^{3}$, bowiem umieszczenie dziecka w pieczy zastępczej zgodnie z Ustawą o wspieraniu rodziny i systemie pieczy zastępczej ma charakter tymczasowy i powinno służyć powrotowi dziecka do jego rodziny. Piecza zastępcza staje się uzupełnieniem pieczy rodzicielskiej, a nie formą, która pieczę rodzicielską zastępuje z założenia na zawsze. Jednocześnie sytuacja taka prowadzi do funkcjonowania dziecka w dwóch rodzinach: biologicznej oraz zastępczej ${ }^{4}$.

1 Por. K. Błażejewska, Bariery i szanse rodzicielstwa zastępczego. Rodzina zastępcza recepta na kryzys, w: Rodzina we wspótczesnych kontekstach, red. B. Cieślińska, A. Sadowski, Białystok 2014, s. 167-180 (Pogranicze, Studia Społeczne, 24).

Por. Z. Dąbrowski, Pedagogika opiekuńcza w zarysie, Olsztyn 2000, s. 80.

3 Por. A. Zybura, Opieka $i$ wychowanie w rodzinnej pieczy zastępczej. Na przykładzie powiatu ostrowieckiego, „Acta Scientifica Academiae Ostroviensis”. Sectio A, Nauki humanistyczne, społeczne i techniczne, 8 (2016) 2, s. 520-546.

4 Por. D. Wosik-Kawala, Dziecko wychowane $w$ rodzinie zastępczej, „Wychowanie w Rodzinie" 11 (2015) 1, s. 271-288. 
Ustawa o wpieraniu rodziny i systemie pieczy zastępczej określa formalne ramy funkcjonowania rodzin zastępczych. Piecza zastępcza należy do zadań powiatu i ma na celu zapewnienie pracy z rodziną, która będzie umożliwiać powrót dziecka do rodziny biologicznej. Ustawodawca określa, iż w sytuacji gdy nie jest to możliwe, piecza zastępcza powinna dążyć do przysposobienie dziecka lub zagwarantować opiekę i wychowanie w środowisku zastępczym ${ }^{5}$.

Organizatorem rodzinnej pieczy zastępczej jest wyznaczona przez starostę jednostka organizacyjna powiatu lub podmiot, któremu powiat zlecił realizację tego zadania. W sytuacji gdy organizatorem rodzinnej pieczy zastępczej jest powiatowe centrum pomocy rodzinie, wówczas tworzy się tam zespół do spraw rodzinnej pieczy zastępczej. Do zadań organizatora rodzinnej pieczy zastępczej należy prowadzenie naboru kandydatów do pełnienia funkcji rodziny zastępczej, organizowanie szkoleń dla kandydatów, zapewnienie szkoleń rodzinom zastępczym w celu podnoszenia ich kwalifikacji ${ }^{6}$.

Schemat organizowania pieczy zastępczej dzieli się na udzielenie pomocy oraz wsparcia o charakterze instytucjonalnym i rodzinnym. Do instytucjonalnych form pieczy zastępczej zalicza się:

- placówki opiekuńczo-wychowawcze;

- regionalne placówki opiekuńczo-terapeutyczne;

- interwencyjne ośrodki preadopcyjne ${ }^{7}$.

Z kolei w rodzinnej pieczy zastępczej wyróżniamy rodzinę zastępczą:

- spokrewnioną;

- niezawodową;

- zawodową, w tym zawodową pełniącą funkcję pogotowania rodzinnego i zawodową specjalistyczną .

Obecnie w Polsce istnieje 37201 rodzin zastępczych, w których przebywa 52049 dzieci. W poniższej tabeli zawarte są dane statystyczne Głównego Urzędu Statystycznego na dzień 31 grudnia 2017 roku, z podziałem na województwa.

5 Ustawa o wspieraniu rodziny i systemie pieczy zastępczej z dnia 9 czerwca $2011 \mathrm{r}$., Dz.U. z 2017 r. art. 32-33.

6 Ustawa o wspieraniu rodziny i systemie pieczy zastępczej z dnia 9 czerwca 2011 r., Dz.U. z 2017 r. art. 76.

7 Ustawa o wspieraniu rodziny i systemie pieczy zastępczej z dnia 9 czerwca $2011 \mathrm{r}$., Dz.U. z 2017 r. art. 93.

8 Ustawa o wspieraniu rodziny i systemie pieczy zastępczej z dnia 9 czerwca 2011 r., Dz.U. z 2017 r. art. 39. 
Tabela 1. Liczba rodzin zastępczych

\begin{tabular}{|l|l|l|}
\hline Stan w dniu 31.12.2017 & \multicolumn{3}{|l|}{ RODZINY ZASTĘPCZ } \\
\hline Województwo & rodziny & dzieci \\
\hline Dolnośląskie & $\mathbf{3 8 9 7}$ & $\mathbf{5 2 2 0}$ \\
\hline Kujawsko-pomorskie & 2124 & 2980 \\
\hline Lubelskie & 1681 & 2365 \\
\hline Lubuskie & 1403 & 1992 \\
\hline Łódzkie & 2937 & 3934 \\
\hline Małopolskie & 2020 & 2820 \\
\hline Mazowieckie & $\mathbf{4 2 1 5}$ & $\mathbf{5 7 5 3}$ \\
\hline Opolskie & 1005 & 1374 \\
\hline Podkarpackie & 1272 & 1845 \\
\hline Podlaskie & 898 & 1292 \\
\hline Pomorskie & 2311 & 3346 \\
\hline Śląskie & $\mathbf{5 1 4 5}$ & $\mathbf{7 1 8 0}$ \\
\hline Świętokrzyskie & 974 & 1336 \\
\hline Warmińsko-mazurskie & 1854 & 2685 \\
\hline Wielkopolskie & 3040 & 4545 \\
\hline Zachodniopomorskie & 2425 & 3382 \\
\hline
\end{tabular}

Żródło: opracowanie własne za podstawie sprawozdania Głównego Urzędu Statystycznego w 2017 roku$^{9}$.

Jak wynika z analizy powyższych statystyk, najwięcej rodzin zastępczych oraz dzieci, które w niej przebywają, jest w województwie śląskim, dolnośląskim i mazowieckim.

Poniżej w tabeli zamieszczone zostały dane statystyczne dotyczące rodzinnej pieczy zastępczej z podziałem na typy w latach 2005-2017 na podstawie danych Ministerstwa Pracy i Polityki Społecznej Departamentu Polityki Rodzinnej ${ }^{10}$.

\footnotetext{
9 https://stat.gov.pl/obszary-tematyczne/dzieci-i-rodzina/dzieci/rodzinna-piecza-zastepcza-w-2017-roku,1,2.html\# (10.09.2018).

10 https://www.mpips.gov.pl/wsparcie-dla-rodzin-z-dziecmi/opieka-zastepcza-naddzieckiem/sprawozdania-z-realizacji-ustawy-o-wspieraniu-rodziny-i-systemie-pieczy-zasteczej/informacja-rady-ministrow-o-realizacji-w-roku-2017-ustawy-z-dnia-9-czerwca2011-ro-wspieraniu-rodziny-i-systemie-pieczy-zasteczej/ (12.10.2018), https://www.mpips. gov.pl/wsparcie-dla-rodzin-z-dziecmi/opieka-zastepcza-nad-dzieckiem/dane-statystyczne/ (13.10.2018).
} 

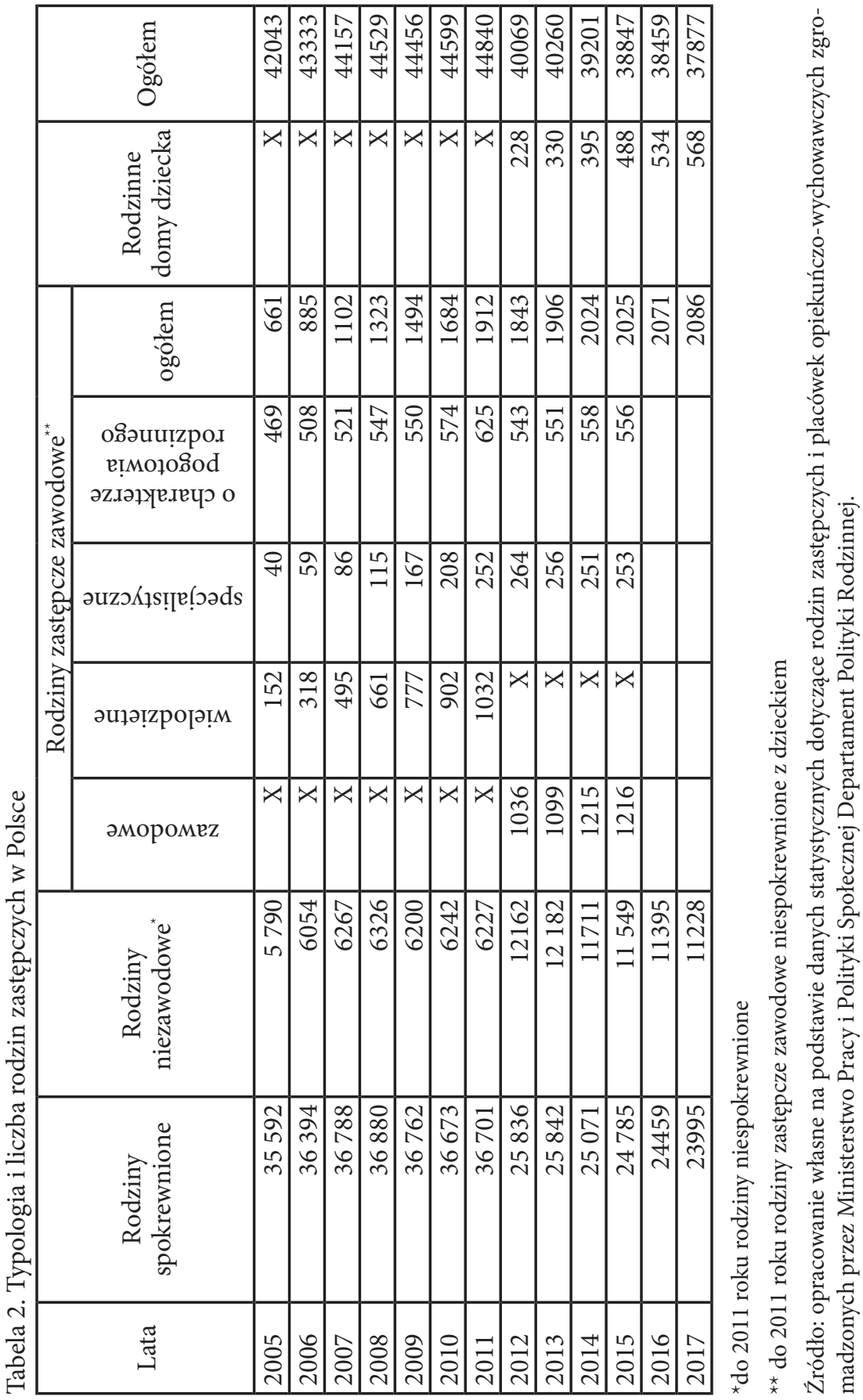
Należy podkreślić, iż ustawa o wspieraniu rodziny i systemie pieczy zastępczej zmieniła typologię oraz nazewnictwo niektórych form pieczy zastępczej. Według nowej systematyki rodzinę spokrewnioną tworzą jedynie wstępni (dziadkowie) lub rodzeństwo dziecka, z kolei rodziny niespokrewnione zostały przekształcone w rodziny niezawodowe (wcześniej pozostali krewni również byli zaliczani do grupy rodzin spokrewnionych). Zatem wzrost liczby rodzin niezawodowych pomiędzy 2011 (6 227 rodzin ) a 2012 (12 162 rodzin) wynika ze zmiany nazewnictwa poszczególnych form pieczy zastępczej.

Zadaniem rodziny zastępczej jest zapewnienie dziecku całodobowej opieki oraz wychowania, dostępu do świadczeń zdrowotnych, kształcenia, a także wyrównywania braków rozwojowych i edukacyjnych. Opiekunowie zastępczy powinni zaspokajać potrzeby emocjonalne, bytowe, społeczne oraz religijne dziecka ${ }^{11}$. Rodzina zastępcza ma niewątpliwie fundamentalne znaczenie w wychowaniu dziecka, a także przekazaniu pożądanych społecznie zachowań i norm. Rodzina bowiem oddziałuje na socjalizację dziecka poprzez zapewnienie odpowiednich warunków materialno-bytowych, status społeczny, cechy osobowości, sposób życia, rozwój swoich kompetencji ${ }^{12}$.

\section{Zasada subsydiarności w pomocy społecznej}

Zasada pomocniczości zakłada udzielenie takich świadczeń pomocy społecznej jednostkom, które pomimo starań nie są w stanie ich pokonać i prowadzić samodzielnego życia. Wszelkie działania pomocowe wyższych grup społecznych powinny być ukierunkowane na dobro rodziny w celu niwelowania bądź ograniczenia bezradności i bierności życiowej beneficjentów niższej grupy. Warto zatem przybliżyć genezę zasady subsydiarności w nauce społecznej Kościoła.

Ojciec święty Leon XIII w encyklice Rerum novarum pisał: „Chcieć więc, żeby władza świecka przenikała swym rządem aż do wnętrza domu, jest błędem wielkim i zgubnym. Z pewnością jeśli się jakaś rodzina znajdzie

11 Ustawa o wspieraniu rodziny i systemie pieczy zastępczej z dnia 9 czerwca $2011 \mathrm{r}$, Dz.U. z 2017 r. art. 40.

12 Por. U. Kusio, Rodzina zastępcza jako środowisko wychowawcze. Studium socjologiczne na przykładzie Lublina, Lublin 1998, s. 71. 
w wielkich trudnościach i bez rady, że sama z nich się wyzwolić nie może, jest rzeczą słuszną, by jej w tych ostatecznościach państwo udzieliło pomocy; rodziny bowiem są cząstkami państwa. Tak samo, kiedy w obrębie czterech ścian domu przyjdzie do poważnego podeptania praw wzajemnych, niech wówczas władza państwowa odda każdemu, co mu się należy; będzie to nie pochłanianiem praw obywatelskich, ale ich obroną i wykonywaniem słusznej, a powinnej opieki"13.

Papież zdefiniował obowiązki państwa wodniesieniu do obywateli. Państwo jako organ powinno pomagać rodzinom, ale nie zastępować relacji społecznych. Udzielana pomoc ma być czymś wynikającym z trudnych okoliczności. Państwo nie może zastąpić matki czy ojca, a także lokalnych samorządów:

Prawo wymaga, żeby ani jednostka, ani rodzina nie była pochłaniana przez państwo; jest więc rzeczą słuszną, by i jednostka, i rodzina miała swobodę działania, jak długo nie zagraża dobru powszechnemu lub nie wyrządza krzywdy bliźniemu. Niemniej obowiązkiem rządów jest czuwać nad społeczeństwem i nad jego częściami składowymi. „Nad społeczeństwem”, albowiem natura powierzyła je staraniom zwierzchniej władzy tak dalece, iż troska o dobro powszechne nie tylko prawem najwyższym jest dla władzy; ale jeszcze źródłem i celem; a zaś „nad częściami składowymi społeczeństwa", albowiem odpowiednio do prawa natury rząd powinien mieć na oku nie interes osób rządy sprawujących, ale dobro tych, którzy mu są poddani. Oto nauka zarówno filozofii, jak i wiary chrześcijańskiej. Że zaś władza rządzenia od Boga pochodzi i do pewnego stopnia jest uczestnictwem w Jego najwyższym władztwie, przeto winno się ją sprawować według wzoru Boskiej władzy, która po ojcowsku kieruje sprawami jednostki i ogółu. Jeśli zatem interesy bądź ogółu, bądź jednej klasy społecznej zostały naruszone lub zagrożone, a nie ma już innych środków zaradczych, wówczas należy uciec się do władzy publicznej ${ }^{14}$.

Zasada pomocniczości została także mocno akcentowana w nauczaniu społecznym Piusa XI. W encyklice o odnowieniu ustroju społecznego Quadragesimo anno ojciec święty podkreślał: „Jak nie wolno jednostkom wydzierać i na społeczeństwo przenosić tego, co mogą wykonać z własnej inicjatywy i własnymi siłami, podobnie niesprawiedliwością, szkodą spo-

\footnotetext{
13 Leon XIII, enc. Rerum Novarum, 11.

14 Leon XIII, enc. Rerum Novarum, 28.
} 
łeczną i zakłóceniem porządku jest zabierać mniejszym i niższym społecznościom te zadania, które mogą spełnić, i przekazywać je społecznościom większym i wyższym. Wszelka bowiem działalność społeczna winna wspomagać człony społecznego organizmu, nigdy zaś ich nie niszczyć, ani nie wchłaniać"15. Pontyfikat Piusa XI przypadł na trudne czasy totalitaryzmu, dlatego papież nawoływał do odnowy ustroju społecznego. Mobilizując do odbudowy struktur organizacji społecznych niższego rzędu, podkreślał, iż nienaruszalnym prawem jednostki jest prawo do podejmowania różnorodnych działań.

Katechizm Kościoła katolickiego przyjął definicję zasady pomocniczości, odwołując się do sformułowania zawartego w encyklice Jana Pawła II Centesimus annus: „Socjalizacja niesie także pewne niebezpieczeństwa. Zbyt daleko posunięta interwencja państwa może zagrażać osobistej wolności i inicjatywie. Nauczanie Kościoła wypracowało zasadę nazywaną zasadą pomocniczości. Według niej społeczność wyższego rzędu nie powinna ingerować $\mathrm{w}$ wewnętrzne sprawy społeczności niższego rzędu, pozbawiając ją kompetencji, lecz raczej powinna wspierać ją w razie konieczności i pomóc w koordynacji jej działań z działaniami innych grup społecznych, dla dobra wspólnego"16.

Zastosowanie zasady subsydiarności pozwala na podejmowanie decyzji jak najbliżej obywateli, zakładając także współpracę między samorządem a społecznością lokalną. Zdaniem Arkadiusza Wuwera „charakterystycznym następstwem pomocniczości jest uczestnictwo, zasadniczo wyrażające się w działaniach, dzięki którym obywatel jako jednostka lub w stowarzyszeniu z innymi, bezpośrednio albo poprzez swoich reprezentantów, wnosi swój wkład w życie kulturalne, ekonomiczne, społeczne i polityczne wspólnoty obywatelskiej, do której należy"17.

Ustawa o pomocy społecznej ${ }^{18}$ nie używa terminu zasady pomocniczości w sposób bezpośredni, jednak można ją wyinterpretować z treści określającej zasady udzielania wsparcia. Sprowadza się do niewyręczania jed-

\footnotetext{
15 Pius XI, enc. Quadragesimo anno, 5.

16 Katechizm Kościoła Katolickiego, Poznań 2002, wyd. II, 1883, Jan Paweł II, enc. Centesimus annus, 48.

17 A. Wuwer, Zasada subsydiarności. Perspektywa nauczania społecznego Kościoła, Katowice 2011, s. 168.

18 Ustawa z dnia 12 marca 2004 r. o pomocy społecznej (tekst jedn. Dz.U. 2016 poz. 930z późn. $z m$.$) .$
} 
nostki z zadań, które osoba może samodzielnie wypełnić. Pomoc społeczna ma być udzielana tylko wówczas, gdy jednostka, rodzina, grupa społeczna przestaje być samowystarczalna w pełnieniu ról społecznych. Ustawodawca podkreśla, iż muszą być spełnione dwie przesłanki, aby pomoc społeczna mogła by realizowana. Pierwszą z nich jest wystąpienie trudnej sytuacji życiowej, jednak nie jest ona jednoznacznie zdefiniowana ${ }^{19}$. Podane są przyczyny powstania trudnej sytuacji życiowej, m.in.: bieda, sieroctwo, bezdomność, niepełnosprawność, bezrobocie, przemoc w rodzinie, bezradność w sprawach opiekuńczo-wychowawczych oraz prowadzenia gospodarstwa domowego, potrzeba ochrony macierzyństwa i wielodzietności, uzależnienia, sytuacja kryzysowa, zdarzenia losowe, klęski żywiołowe ${ }^{20}$. Drugą przesłanką jest brak samodzielności w przezwyciężeniu ww. trudnych sytuacji życiowych, którą ustawodawca określa jako zbiór własnych uprawnień, umiejętności, zasobów, możliwości ${ }^{21}$. „Wśród tez zasady subsydiarności mieści się tzw. pomoc do samopomocy (subsydiarne towarzyszenie) oraz przejściowy charakter pomocy połączony z aktywizacją beneficjenta (subsydiarna redukcja)"22.

Ustawa o wspieraniu rodziny i systemie pieczy zastępczej podkreśla, iż wszelkie działania związane z pomocą dziecku i rodzinie, które są zawarte w Ustawie o wspieraniu rodziny i systemie pieczy zastępczej, powinny być realizowane zgodnie z zasadą pomocniczości ${ }^{23}$. Ustawodawca zaznacza, iż najważniejsza jest podmiotowość dziecka i rodziny. Stosując ustawę, należy mieć na względzie prawo dziecka do wychowania w rodzinie. Umieszczenie dziecka w rodzinnych formach zastępczych musi być zgodne z dobrem dziecka, zapewnieniem mu stabilnego środowiska wychowawczego, a także możliwości kształcenia, rozwoju uzdolnień, zainteresowań oraz form wypoczynku. Należy także zapewnić utrzymanie osobistych kontaktów z rodzica$\mathrm{mi}, \mathrm{z}$ wyjątkiem sytuacji gdy sąd postanowił inaczej ${ }^{24}$.

19 I. Sierpowska, Zasada pomocniczości w pomocy społecznej, „Acta Universitatis Wratislaviensis, Przegląd Prawa i Administracji” 79 (2009), s. 209.

20 Ustawa $z$ dnia 12 marca 2004 r. o pomocy społecznej (tekst jedn. Dz.U. 2016 poz. 930z późn. zm.).

21 Por. I. Sierpowska, Zasada pomocniczości..., dz. cyt., s. 209.

22 I. Sierpowska, Zasada pomocniczości..., dz. cyt., s. 210.

23 Ustawa o wspieraniu rodziny i systemie pieczy zastępczej z dnia 9.06.2011 r., Dz.U. z 2017 r. art. 3.

24 Por. Ustawa o wspieraniu rodziny i systemie pieczy zastępczej z dnia 9.06.2011 r., Dz.U. z 2017 r. art. 4. 
Pomoc społeczna, której celem jest dobro dziecka, powinna udzielać takich form wsparcia i pomocy dla osób niewydolnych wychowawczo, by ograniczyć ich postawę bierności i bezradności życiowej. Działania pomocowe powinny być dostosowane do potrzeb jednostki, uwzględniając jej możliwości, a także ograniczenia. Zatem głównym zadaniem pomocy społecznej jest udzielenie skutecznej pomocy, która będzie pobudzać beneficjentów do samodzielnego i aktywnego życia w społeczeństwie.

\section{System wsparcia wychowanków pieczy zastępczej}

Koordynator rodzinnej pieczy zastępczej wspiera rodzinę zastępczą w realizowaniu zadań ujętych w ustawie. Jak wynika z przepisów, koordynator może mieć pod opieką nie więcej niż 15 rodzin. Zobowiązany jest do systematycznego podnoszenia swoich kwalifikacji poprzez udział w szkoleniach bądź samokształceniu. Do zadań koordynatora rodzinnej pieczy zastępczej należy opracowanie we współpracy z rodziną zastępczą planu pomocy dziecku, zgłaszanie do ośrodków adopcyjnych informacji o dzieciach, które mają uregulowaną sytuację prawną, w celu poszukiwania dla nich rodzin adopcyjnych, a także udzielenie wsparcia usamodzielnianym wychowankom ${ }^{25}$. Należy podkreślić, iż rola koordynatora ma duże znaczenie dla prawidłowego funkcjonowania systemu pieczy zastępczej, bowiem jego zadaniem jest zapewnienie poczucia bezpieczeństwa dziecku oraz rodzinie zastępczej. Funkcja koordynatora ma charakter wpierający, polega na udzieleniu pomocy oraz wskazówek w rozwiązywaniu trudnych sytuacji związanych z opieką i wychowaniem dziecka. Wydaje się jednak, iż zawód koordynatora utożsamiany jest z rolą urzędnika, osoby kontrolującej. Może to wynikać z faktu ogromnej pracy biurowej obwarowanej przepisami prawnymi (tworzenie planu pomocy dziecku, ocena sytuacji dziecka, ocena rodziny zastępczej), a także z rotacją pracowników (niedocenienie pracy w pomocy społecznej).

Ustawodawca określił zasady funkcjonowania organizatora rodzinnej pieczy zastępczej, które mają zapewnić właściwe systemowe wsparcie rodzin zastępczych. Jednym z tych zadań jest przygotowanie posiedzenia do

25 Por. Ustawa o wspieraniu rodziny i systemie pieczy zastępczej z dnia 9.06.2011 r., Dz.U. z 2017 r. art. 77. 
spraw oceny sytuacji dziecka umieszczonego w rodzinie zastępczej. Posiedzenia powinny się odbywać nie rzadziej niż co 6 miesięcy, a w przypadku dzieci do 3 roku życia nie rzadziej niż co 3 miesiące ${ }^{26}$. W spotkaniu biorą udział rodzina zastępcza, koordynator, przedstawiciel organizatora rodzinnej pieczy zastępczej, a także psycholog, reprezentant ośrodka adopcyjnego, rodzice biologiczni oraz ich asystent rodziny. Zespół interdyscyplinarny może być uzupełniany o inne osoby, które mogą udzielić istotnych uwag związanych z funkcjonowaniem dziecka, np. nauczyciel, kurator, pedagog 27 .

Ponadto ustawa daje możliwość kontrolowania rodzin zastępczych i organizatora rodzinnej pieczy zastępczej. Zadanie to zleca się zarządowi powiatu. Koordynator nie ma funkcji kontrolującej, jego rola sprowadza się do wspierania rodziny, wzbudzania zaufania i poczucia bezpieczeństwa ${ }^{28}$.

Należy podkreślić, jak ważne jest wsparcie koordynatora rodzinnej pieczy zastępczej, zwłaszcza nawiązanie prawidłowej relacji z rodziną zastępczą oraz dzieckiem, dla funkcjonowania, a także rozwoju systemu pieczy zastępczej. Koordynator jako osoba z „zewnątrz”, spotykając się z podopiecznymi, prowadząc obserwacje, rozmowy, ma szansę dostrzec, jakie trudności pojawiają się w wychowaniu dziecka ${ }^{29}$. Rola koordynatora ma wszechstronny wymiar: do jego obowiązków należą interdyscyplinarne działania. Istotną rolą koordynatora jest współpraca ze szkołami, z przedszkolami, sądem rodzinnym, kuratorami, asystentami rodziny.

Dziecko, które zostaje umieszczone w rodzinie zastępczej, niezależnie od wieku ma ogromny bagaż doświadczeń. Większość podopiecznych od urodzenia doświadczała wielu trudności, była narażona na urazy, często nie respektowano ich praw, a także nie zaspokajano ich podstawowych potrzeb. Doświadczenia traumatyczne, bolesne są niewątpliwie trudne do zrozumienia dla samego dziecka, a także dla rodziny zastępczej. Świadomość porzucenia, utraty bliskiej osoby, w tym przypadku rodziców biologicznych, niesie za sobą wiele negatywnych emocji oraz przeżyć. Zerwanie więzi emocjonalnych z rodzicami często powoduje u dziecka lęk, poczucie

26 Por. Ustawa o wspieraniu rodziny i systemie pieczy zastępczej z dnia 9.06.2011 r., Dz.U. z 2017 r. art. 131.

27 Por. Ustawa o wspieraniu rodziny i systemie pieczy zastępczej z dnia 9.06.2011 r., Dz.U. z 2017 r. art. 130.

28 Por. T. Gebel, Koordynator rodzinnej pieczy zastępczej i jego rola $w$ systemie pieczy zastępczej, „Lubuski Rocznik Pedagogiczny” 36 (2017) 3, s. 225-232.

29 Por. T. Gebel, Koordynator rodzinnej pieczy zastępczej i jego rola $w$ systemie pieczy zastępczej, dz. cyt., s. 230. 
osamotnienia, trudność w nawiązaniu bliskich relacji z innymi; z kolei potrzeba miłości, bliskości może być wypierana. Konsekwencją tych przeżyć jest najczęściej stan protestu, który objawia się bezsennością, zaburzeniami nastroju, poczuciem winy, zaburzeniem koncentracji i uwagi ${ }^{30}$.

Zadanie rodziców zastępczych polega na stworzeniu takiego środowiska, które zapewni dziecku poczucie bezpieczeństwa, właściwe rozpoznanie i zaspokajanie potrzeb, szacunek dla jego tożsamości i znaczących relacji, rozwój potencjału, zdolności i zainteresowań. Opieka nad dzieckiem przyjętym jest wielowymiarowym obowiązkiem, do którego zarówno rodzice zastępczy, jak i zespół wspierający dziecko powinni być należycie przygotowani. Przywiązanie ma fundamentalne znaczenie dla bezpiecznej rodzinnej opieki zastępczej. Chodzi zatem o wytworzenie prawidłowych więzi emocjonalnych pomiędzy dzieckiem, które potrzebuje opiekim, a dorosłym opiekunem, który tę opiekę zapewnia ${ }^{31}$.

Dziecko umieszczone w rodzinie zastępczej nieustannie uwikłane jest w konflikt lojalnościowy między rodzicami biologicznymi i zastępczymi. Podopieczny wychowany w dwóch środowiskach wychowawczych może doświadczyć różnic w rozmaitych aspektach: innej hierarchii wartości, przekazywania norm zachowania społecznego, sposobów spędzania wolnego czasu. Wobec traumatycznych przeżyć związanych z porzuceniem dziecko przeżywa dramat wewnętrzny, który dotyczy funkcjonowania emocjonalnego, psychicznego, intelektualnego, a także jest on związany z kryzysem tożsamości ${ }^{32}$. U dzieci przebywających w rodzinach zastępczych można zdiagnozować zaburzenia więzi, które są skutkiem braku utworzenia prawidłowych więzi we wczesnym dzieciństwie. Negatywne przeżycia z rodzin biologicznych mają wpływ na brak zaufania i lęk względem osób dorosłych. Dziecko umieszczone w zastępczej rodzinie początkowo inicjuje kontakty pozorne i powierzchniowe. $\mathrm{Z}$ upływem czasu, w trakcie nawiązywania głębszych relacji, pojawia się u niego tendencja do powielania zachowań,

30 Por. A. Chrostowska-Buzun, Obraz ciała u dziecka po traumie, s. 3, http://ipp.waw. pl/files/Anna_Chrostowska-Buzun.pdf (16.10.2018).

31 Por. Biuro Rzecznika Praw Dziecka, Kodeks bezpiecznej opieki w rodzicielstwie zastępczym, s. 31. http://brpd.gov.pl/sites/default/files/internet_kodeks_bezpiecznej_opieki_w _rodzicielstwie_zasepczym.pdf (15.10.2018).

32 Por. A. Chrostowska-Buzun, Obraz ciała u dziecka po traumie, dz. cyt., s. 3-4. 
wówczas wychowanek może prowokować odrzucenie, którego doświadczyło w dzieciństwie ${ }^{33}$.

Problem, z którym borykają się dzieci, a także opiekunowie zastępczy, to FASD - spektrum płodowych zaburzeń alkoholowych (Fetal Alcohol Spectrum Disorder), czyli nieuleczalne zaburzenia fizyczne i psychiczne. Termin ten opisuje problem zdrowotny i zaburzenia zachowania wynikające z uszkodzenia mózgu płodu przez alkohol. Nieprawidłowy przebieg procesu rozwoju mózgu w życiu płodowym wiąże się z charakterystycznymi zmianami na twarzy dziecka, opisywany jest jako Płodowy Zespół Alkohol - FAS (Fetal Alcohol Syndrome). Charakterystycznymi cechami dzieci z FAS są trudności z koncentracją, nadaktywność, problemy z zapamiętywaniem, brak umiejętności rozpoznawania konsekwencji swoich działań ${ }^{34}$.

Opiekunowie zastępczy często nie mają wiedzy o syndromie FAS i sposobach rozwiązywania problemów uwzględniających specyfikę tego rodzaju zaburzeń fizyczno-psychicznych. Dlatego ważnym elementem w systemie wsparcia rodziny zastępczej z dzieckiem jest przeprowadzenie szkoleń, a także pomoc w zdiagnozowaniu wychowanka. Osoby zajmujące się diagnostyką oraz pracą z dziećmi z FASD wypracowali 10 praw dotyczących ich wychowania:

1. Konkretność - dzieci mają ograniczoną możliwość zapamiętywania, znaczne deficyty uwagi. Wymagają formułowania konkretnych poleceń, komunikowania oczekiwań. Opis polecenia powinien być jasny i zawarty w krótkim zdaniu. Dzieci wymagają dłuższego czasu na wykonanie danego działania.

2. Stałość - większość dzieci ma zaburzone poczucie rytmu dnia. Nie lubią częstych zmian, zaskakujących wydarzeń, potrzebują stałości oczekiwań, stałego rytmu dnia.

3. Powtarzanie - wynika z zaburzeń pamięci i słabej koncentracji uwagi, dlatego ważne jest częste powtarzanie komunikatów, poleceń.

4. Rutyna - zwłaszcza dotycząca stałego rytmu dnia, codziennych obowiązków domowych, szkolnych. Zapewnienie rutyny pozwala dziecku czuć się bezpiecznie, zmniejsza jego frustrację.

33 Por. M. Nowak, A. Gawęda, M. Janas-Kozik, Prowokacja odrzucenia czy pragnienie bliskości? Znaczenie relacji rodzic zastępczy-dziecko dla niwelowania deficytów wynikających $z$ diagnozy „zaburzenia więzi”, „Psychiatria i Psychologia Kliniczna” 11 (2011) 1, s. 60-61.

34 Por. K. Okulicz-Kozaryn, M. Borkowska, Diagnoza FASD dla celów edukacyjnych i wychowawczych, „Przegląd Pedagogiczny” (2015) 1, s. 168-183. 
5. Prostota w komunikowaniu się, wydawaniu poleceń. Dzieci z FAS mają problemy z rozumieniem tekstu czytanego, rozumieniem nieprecyzyjnych poleceń. Dlatego jasność w przekazywaniu treści jest niezwykle istotna dla dziecka.

6. Szczegółowość wypowiedzi, która ma być prosta, ale także bardzo konkretna. Dziecko potrzebuje wiedzieć, czego opiekun naprawdę oczekuje.

7. Zasady - które zawierają wszystkie wcześniejsze cechy. Dziecko potrzebuje zasad, które obowiązują w domu, w szkole, dzięki którym czuje się bezpiecznie i komfortowo.

8. Nadzór - związany jest z kontrolą dziecka, gdyż ma ono problem z planowaniem działań i przewidywaniem ich skutków. Niezapewnienie kontroli może skutkować zachowaniami zagrażającymi bezpieczeństwu dziecka i innych.

9. Interwencje - opiekunowie zastępczy mają trudne zadanie, gdyż dziecko z FAS wymaga stałej obecności i uwagi.

10. Akceptacja - należy pogodzić się z wieloma zachowaniami, które często odbiegają od normy. Dzieci z FAS wymagają ogromnej pracy, zaangażowania, a także poczucia bliskości, miłości, bycia szanowanym i akceptowanym ${ }^{35}$.

\section{Zakończenie}

Dziecko w rodzinie zastępczej boryka się z różnorodnymi problemami, zaburzeniami. Dlatego ważne jest, aby system wsparcia obejmował szeroki wachlarz pomocy wychowankowi, w celu jego prawidłowego rozwoju, a następnie samodzielnego wkroczenia w dorosłość i pełnienia ról społecznych. Zasada pomocniczości zakłada, iż należy udzielić tyle pomocy, ile trzeba. Państwo opiekuńcze nie może wyręczać jednostek z pełnienia ról społecznych, lecz powinno wspierać i motywować do samodzielnego zaspokajania swoich potrzeb.

Rodzicielstwo zastępcze jest wspaniałą misją niesienia pomocy młodym ludziom, dzięki której mogą być kompensowane braki i deficyty, będące efektem niewydolności wychowawczej ich rodziców biologicznych. Prawi-

35 Por. K. Liszcz, Zrozumieć dziecko z FASD, Warszawa 2015, s. 10-13. 
dłowo udzielana pomoc opiekunów zastępczych, a także korzystanie z innych form wsparcia (psycholog, pedagog, terapeuta) mogą przyczynić się do skutecznego usamodzielnienia się wychowanków i pełnienia ról społecznych bez korzystania z pomocy społecznej. Zatem wyzwaniem dla rodzin zastępczych jest pobudzanie i stymulowanie dziecka do samodzielności i aktywności społecznej.

Podsumowaniem niech będą słowa papieża Jana Pawła II, który w encyklice Evangelium vitae pisze:

Rodzina jest powołana, aby spełniać swoje zadania w ciągu całego życia swoich członków, od narodzin do śmierci. Jest prawdziwym „sanktuarium życia [...] miejscem, w którym życie, dar Boga, może w sposób właściwy być przyjęte i chronione przed licznymi atakami, na które jest ono wystawione, może też rozwijać się zgodnie z wymogami prawdziwego ludzkiego wzrostu". W ten sposób wysławianie przekształca się w służbę Ewangelii życia, której wyrazem jest solidarność, doświadczana wewnątrz i na zewnątrz rodziny jako czujna i serdeczna troska, a okazywana przez drobne i skromne gesty każdego dnia. Szczególnie wymownym znakiem solidarności między rodzinami jest adopcja lub wzięcie pod opiekę dzieci porzuconych przez rodziców czy też żyjących w trudnych warunkach. Niezależnie od związków ciała i krwi prawdziwa miłość ojcowska i macierzyńska gotowa jest przyjąć także dzieci pochodzące z innych rodzin, obdarzając je tym wszystkim, co jest im potrzebne do życia i pełnego rozwoju"36.

\section{Bibliografia}

\section{Dokumenty Kościoła}

Jan Paweł II, Encyklika Evangelium Vitae.

Katechizm Kościoła Katolickiego, Poznań 2002, wyd. II, 1883.

Jan Paweł II, Encyklika Centesimus annus.

Leon XIII, Encyklika Rerum Novarum.

Pius XI, Encyklika Quadragesimo Anno.

36 Jan Paweł II, enc. Evangelium vitae, 92-93. 


\section{Dokumenty prawne}

Ustawa o wspieraniu rodziny i systemie pieczy zastępczej z dnia 9 czerwca 2011 r., Dz.U. 2018.0 .998 t.j.

Ustawa z dnia 12 marca 2004 r. o pomocy społecznej (tekst jedn. Dz.U. 2016 poz. 930 z późn. zm.).

\section{Literatura}

Błażejewska K., Bariery i szanse rodzicielstwa zastępczego. Rodzina zastępcza recepta na kryzys, w: Rodzina we współczesnych kontekstach, red. B. Cieślińska, A. Sadowski, Białystok 2014, s. 167-180 (Pogranicze, Studia Społeczne, 24).

Chrostowska-Buzun A., Obraz ciała u dziecka po traumie, http://ipp.waw. pl/files/Anna_Chrostowska-Buzun.pdf (16.10.2018).

Dąbrowski Z., Pedagogika opiekuńcza w zarysie, Olsztyn 2000.

Gebel T., Koordynator rodzinnej pieczy zastępczej i jego rola w systemie pieczy zastępczej, „Lubuski Rocznik Pedagogiczny” 36 (2017) z. 3, s. 225-232.

Biuro Rzecznika Praw Dziecka, Kodeks bezpiecznej opieki w rodzicielstwie zastępczym, http://brpd.gov.pl/sites/default/files/internet_kodeks_bezpiecznej_opieki_w_rodzicielstwie_zasepczym.pdf (15.10.2018).

Kusio U., Rodzina zastępcza jako środowisko wychowawcze. Studium socjologiczne na przykładzie Lublina, Lublin 1998.

Liszcz K., Zrozumieć dziecko z FASD, Warszawa 2015.

Nowak M., Gawęda A., Janas-Kozik M., Prowokacja odrzucenia czy pragnienie bliskości? Znaczenie relacji rodzic zastępczy-dziecko dla niwelowania deficytów wynikajacych z diagnozy „zaburzenia więzi”, „Psychiatria i Psychologia Kliniczna” 11 (2011) 1, s. 59-63.

Okulicz-Kozaryn K., Borkowska M., Diagnoza FASD dla celów edukacyjnych i wychowawczych, „Przegląd Pedagogiczny” (2015)1, s. 168-183.

Sierpowska I., Zasada pomocniczości w pomocy społecznej, „Acta Universitatis Wratislaviensis, Przegląd Prawa i Administracji” 79 (2009), s. 204225.

Wosik-Kawala D., Dziecko wychowane w rodzinie zastępczej, „Wychowanie w Rodzinie" 11 (2015) 1, s. 271-288.

Wuwer A., Zasada subsydiarności. Perspektywa nauczania społecznego Kościoła, Katowice 2011. 
Zybura A., Opieka i wychowanie w rodzinnej pieczy zastępczej. Na przykładzie powiatu ostrowieckiego, „Acta Scientifica Academiae Ostroviensis”. Sectio A, Nauki humanistyczne, społeczne i techniczne, nr 8 (2016) 2, s. 520-546.

Strony internetowe

https://stat.gov.pl/obszary-tematyczne/dzieci-i-rodzina/dzieci/rodzinna-piecza-zastepcza-w-2017-roku,1,2.html\# (10.09.2018).

https://www.mpips.gov.pl/wsparcie-dla-rodzin-z-dziecmi/opieka-zastepcza-nad-dzieckiem/sprawozdania-z-realizacji-ustawy-o-wspieraniu-rodziny-i-systemie-pieczy-zasteczej/informacja-rady-ministrow-o-realizacji-w-roku-2017-ustawy-z-dnia-9-czerwca-2011-ro-wspieraniu-rodziny-i-systemie-pieczy-zasteczej/ (12.10.2018).

https://www.mpips.gov.pl/wsparcie-dla-rodzin-z-dziecmi/opieka-zastepcza-nad-dzieckiem/dane-statystyczne/ (13.10.2018). 
